\title{
Communication as a Way in the Development of Fishing Village in Belawan Medan Indonesia
}

\author{
Beny OY Marpaung \\ Architecture Department. Faculty of Engineering, \\ Universitas Sumatera Utara, Indonesia \\ beny.marpaung@usu.ac.id
}

\begin{abstract}
Fisherman's village is a settlement that is always attached to the coastal city of Belawan in Medan. The study to understand the needs of the community becomes a potential for successful development. The researcher identifies residents' involvement in finding the most appropriate communication as a development strategy. The author uses quantitative and qualitative methods in completing this research. In analyzing, the researcher correlates data interpretation, perception, participation and communication strategy with literature review. The result of this research is a communication model that will encourage the development of Belawan fishing village into a community-based coastal settlement and local wisdom.
\end{abstract}

Keywords: settlement; communication; coastal; strategy

eISSN 2398-4279 @ 2018. The Authors. Published for AMER ABRA cE-Bs by e-International Publishing House, Ltd., UK. This is an open access article under the CC BY-NC-ND license (http://creativecommons.org/licenses/bync-nd/4.0/). Peer-review under responsibility of AMER (Association of Malaysian Environment-Behaviour Researchers), ABRA (Association of Behavioural Researchers on Asians) and $c E-B s$ (Centre for EnvironmentBehaviour Studies), Faculty of Architecture, Planning \& Surveying, Universiti Teknologi MARA, Malaysia.

https://doi.org/10.21834/ajqol.v3i11.120 


\subsection{Introduction}

Communication occupies a decisive role as a whole process. Some mass communication experts argue that the preparation of the design of rural development on the coast should be clear. The implementation situation does not guarantee that it will work well if it does not get support through effective communication. Governments and villagers must work together to manage and develop fishermen's settlements in Belawan. Accessibility and infrastructure to the Fisherman's village are in a bad state. Institutional system, management and Human Resources, and so are still not integrated. There are several concrete steps in developing and assessing the potential of coastal settlements in Belawan Medan. An important concrete step is to examine perceptions and participation. This study is to find a picture of the thoughts and desires of the people so that they have intention in building the settlement area. The community must understand the potential of the village and have the intention to make the village as a habitable settlement. Through the discovery of this study, the authors can make the most appropriate communication model in order to build a habitable settlement. The government would also be easy to carry out counseling to the public. Research on the most appropriate communication action puts the planning and management expectations of development into a clear guarantee and direction.

\subsection{Literature Review}

Studies on how to communicate for successful settlement building are essential. The interest concerns the issue of good communication to people in residential areas, because of the existing inhabitants and the use of the environment (Bishop \& Said, 2011). The role of communication in development should bring about a change in a region. This means that communication activities should be able to anticipate the movement of development. Communication on the life of the community is characterized by the negotiation of a problem related to common interests. This allows the public to express their thoughts and interests through environmental issues. Communication in negotiating the settlement of environmental problems is a tangible form of community participation to improve the quality of life of the inhabitants of the settlements (Akortor, 2012). Communication in development planning requires attention to the principles, methods, and tools of a communication strategy because the concept of sustainable development stems from the incorporation of different fields and approaches (Oppen, 2006). According to Kheerajit and Flor, there are four types of communication in order to carry out active participation to various parties. The communication is related to natural resource management. The four types of communication are consultation, collaboration, information sharing and empowerment of existing parties in the participation system (Kheerajit \& Flor, 2013). Differences of opinion are often present in the communication process. There are several important opinions and stages in the negotiations when there is a difference in the communication process. Handling of multistakeholder and multi-issue disputes is (1) bringing in official representation in accordance with the policy makers of various groups; (2) ensuring that the official representatives and each constituency have the time and resources they need in order for the preparation to proceed effectively; (3) provide non-partisan facilitators to organize discussions; (4) to carry 
out the basic rules of the process of a discussion; And (5) clarify the results of a group product or decision making (Susskind \& friends, 2003). Understanding Strategy influences the planning decisions of development in an area. These strategies include: (1) motivating actors to exist and be active in negotiations; (2) do problem-solving in a good way in a negotiation; And (3) an integrative negotiation from the beginning to the end of the negotiations. Other factors may also affect the strategy in negotiation, namely strength, preference and cultural factors (Dür \& Mateo, 2010). Negotiations must achieve results in accordance with expectations, so the process must have strength. There are several factors that affect the power of negotiation, the factors are (1) Resources in negotiations; (2) voting; (3) economic size; (4) information; and (5) cooperation. (Bailer, 2010).

\subsection{Methodology}

In determining the coastal settlements studied, the authors consider three elements, namely the place, occupants, and activities. Places, occupants, and activities are elements used by researchers in collecting data relating to the identification of perceptions, wishes, and understanding of the community about the physical condition of the settlement area. In determining the technique of determining the sample of researchers using the method "Purposive Sampling" is the technique of determining the sample by considering that respondents can understand the question of perception and desire to involve themselves in development. Researchers distributed questionnaires to respondents who were in the adult category. In this study, the selected sample or resource persons consider villagers who have long lived, know the village situation, open to accept the other side, have a picture of thinking about the settlement, and able to describe the potential of the village for the overall development. Respondents also understood the potential of the village and were able to express what they thought when a development program was applied to the settlements inhabited by them. In determining the variables, researchers first do the interpretation of the theory on which to base. Researchers determine the basis based on issues that will be resolved in the study. Researchers do an analysis of a theory and then make an indicator that the process of thinking based on research problems. Researchers collect data based on research variables. In conducting the analysis, researchers connect data through aspects of perception and desire to involve themselves through the theoretical basis. The results of the analysis of the idea of the village community in influencing communication, participation, communication strategy and perception become the material in making the model of community participation in building fisherman's settlement on the coast of Belawan Medan.

\subsection{Findings and Discussions}

Many inhabitants of the fishing village in Belawan Medan do not have land certificates (94\%). Medan municipal government must create programs and solutions that can prevent the growing growth of illegal settlements in coastal areas. Development programs that affect the quality of the environment and occupancy, will certainly produce the quality of his life (Asturi, Astuty, \& Syarifudin, 2014). In general, the community of Belawan Fishermen Medan has 
heard of settlement construction program for the coastal area (74\%). Community development is an integral part of development. The three phases that affect a country's economic growth are capacity building, community development and social capital factors (Ahmad, Yusof, \& Abdullah, 2013). Coastal communities of settlements have thought that the economic level of local communities will be more developed than before $(61.4 \%)$ if they involve themselves in building a village. People also think that settlements can increase family income (27.2\%). Settlement development provides opportunities for a habitable physical environment. In general, residents of fishing villages in Belawan Medan open themselves when there is potential for marine cultivation in their coastal areas (82\%). The potential of marine aquaculture provides sustained economic improvement although at the beginning of its implementation it is not promising opportunities that will be received by local residents in a significant way. This will then create positive actions from residents of the settlement in conserving local resources and safeguarding natural resources (Prabhakan et al., 2014; Tosun \& Inskeep, 1994). The planning and development of Belawan Medan's fishing village should involve social networks (non-government) and the government so that local people are willing to participate. Local people have a desire to jointly promote the program $(94.5 \%)$. They understand the importance of a program in advancing their village to a better economic progress. Villagers ensure their involvement in the planning and development process by including the agency or program manager (93.4\%). In fact, local people will accept other parties from outside to understand and research about their current dwelling area (96\%). This fact helps the design of efficient and effective participation. Participatory design should design development for the public good (Kang, Choo \& Watters, 2015). The local communities of fishing villages will only be involved in programs that can be felt real by them (57\%) and provide benefits (57\%). This fact illustrates the importance of involving the community in building Belawan fishing village. The community builds fishing settlements based on their thinking. Cultural and social elements play an important role in the formation of coastal settlements in Belawan. Cultural and social research on these coastal settlements requires the openness of local communities. By involving local communities, others will get more quickly on information related to conservation and cultivation. This is very likely because the community should be a source of local knowledge (Daim et al., 2012). Local people have a desire to involve themselves in supporting village conservation if they approve a government program (65\%). Community involvement will certainly facilitate the planning process until the realization of the implementation process (Ismail \& Said, 2015). The local population understands that they play an important role in decision-making for the design of fishing village $(58 \%)$. Based on their perception, the government did not feel the direct decision of the design because it did not live and experience the direct life in the settlement $(27 \%)$. The local population generally wants design products to be oriented towards traditional settlements $(65 \%)$. The designer's view will be oriented to problem-solving, while the design in the business view will be marketing-oriented (Kang, Choo \& Watters, 2014). The planner should be able to solve problems related to the village's thinking about the development program so that monitoring of complex problems can be predicted. According to Shalaby (2013), understanding the causes and problems that occur for a research object can use the model. The model can be a diagram or a frame of 
thought. The model illustrates an analysis of problem-related aspects. A model can be an effective tool for simplifying, predicting, explaining and controlling complex phenomena in different fields of science. Models that describe aspects related to problems in the Belawan Medan fishing village are important to make. Aspects related to the problem should be based on the analysis. This aspect is about the beliefs of local people if the village is in the development program. The villagers of the fishing communities want the coastal settlement development program to open up opportunities for local people (57\%) and the local fishermen's village products will be sold to outsiders (21\%). This fact illustrates that $48 \%$ of fishing communities think that their income in these coastal settlements is sufficient for them to meet all life needs and $39 \%$ say not enough. In this case, the people are eager for the development program in any form to provide benefits to the residents. Local residents are residents who can manage and exploit the potential of the physical environment. Locals in coastal settlements that must preserve, repair and maintain the area (Sesotyaningtyas \& Manaf, 2014). The villagers of the fishing communities have an opinion that the program designed should focus on solving problems (50\%) and even $32 \%$ who want design products to focus on village marketing to outsiders. The program planned in solving the problem will certainly have an impact on the changes. From the cultural aspect, the changes that may occur should prioritize the harmony between local culture and culture outside the settlement $(70 \%)$. Yet there is a $19 \%$ stating that change may occur, insofar as it has no western impact. Local people must also be willing if their place of residence becomes a place of lodging for the newcomers. Local people who accept the concept of accommodation in the homes of people in the development program has become an important potential in the success of the village as a marine tourism destination. This obviously affects high satisfaction levels and new experiences for travelers (Jamalludin, Othman \& Awang, 2012).

Changes will certainly arise through the implementation of development programs. Planners need research to create a program. In order to conduct research to create a program or strategy in an area, it will be very important to establish good communication to people originating in the area (Bishop \& Said, 2011). Communication is a way of shaping the idea of the coastal settlement community. The formation of perception will help the process of developing fishing village in Belawan Medan (figure 1). Planners must find communication strategies through negotiation for a common problem solving in people's lives.

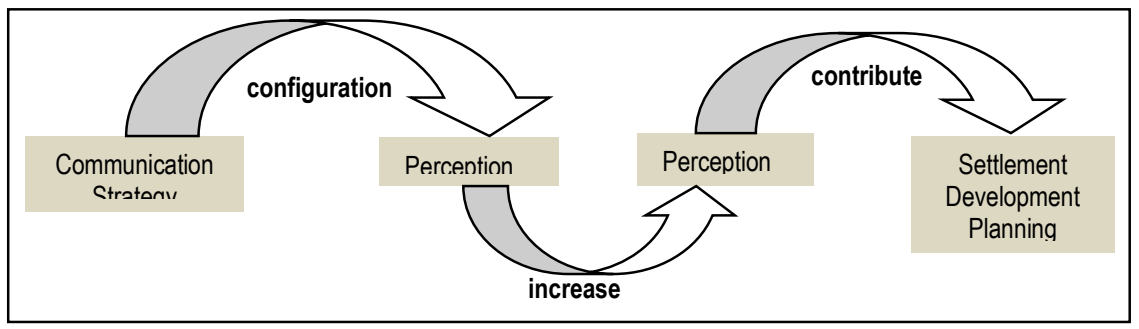

Figure 1: Overview of the Way Communication in Village Development Planning (Source: Author Documentation) 


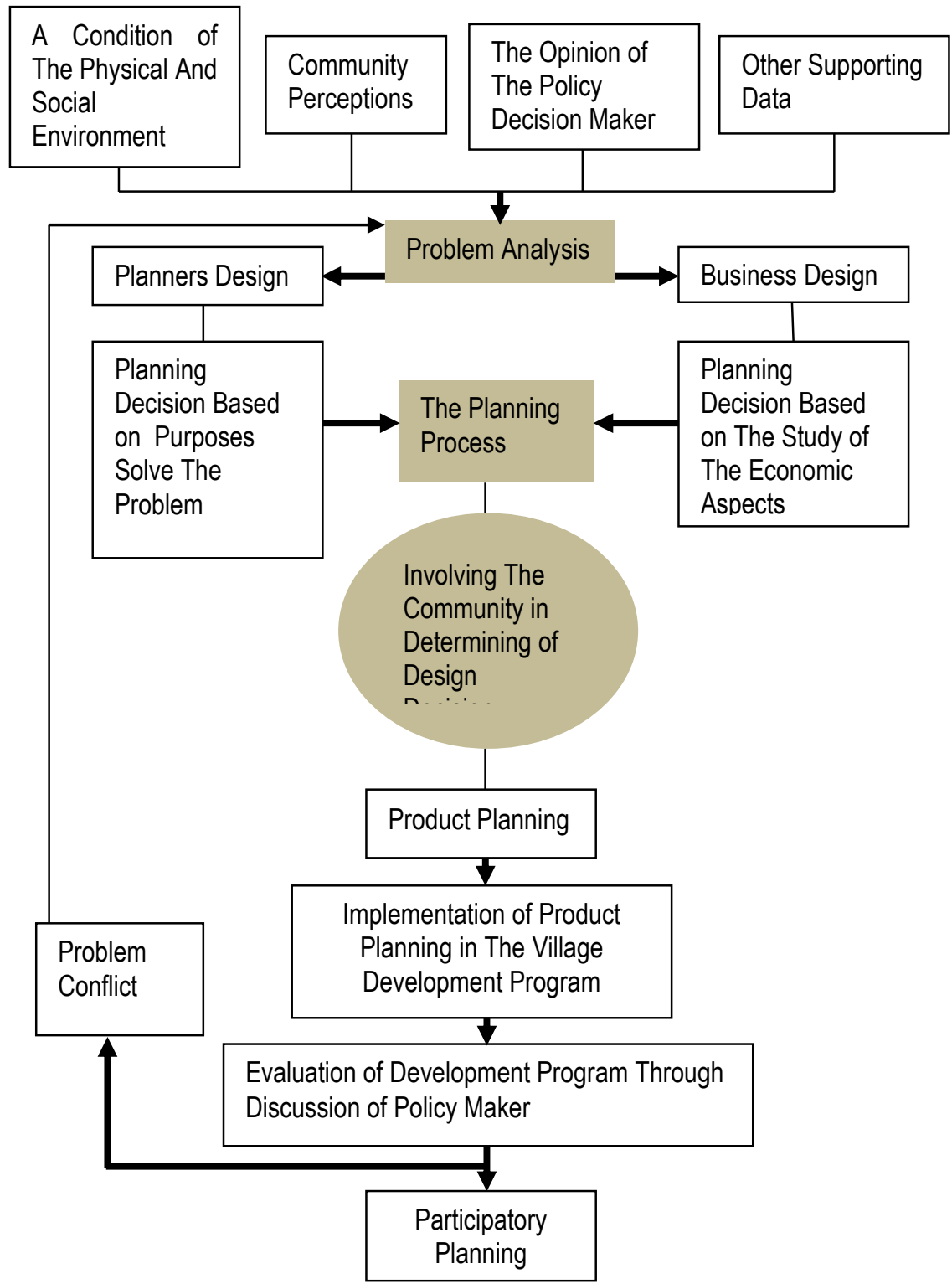

Figure 2: Communication Strategies in Participatory Planning (Source: Author Documentation) 
The community's active role in program planning will help the planners and the government in generating decisions. Program planning requires a participatory concept that can accommodate opinions from all sides (figure 2). The Belawan Fisherman Village community can accept the role of communicators because they are open with the involvement of outsiders. Implementation of appropriate communication strategies prevents conflicts that may occur in the fishing village development program (figure 3). The appropriate and successful communication strategy will provide a positive understanding of the community because it can accommodate opinions from various parties and even involve the community in the implementation.

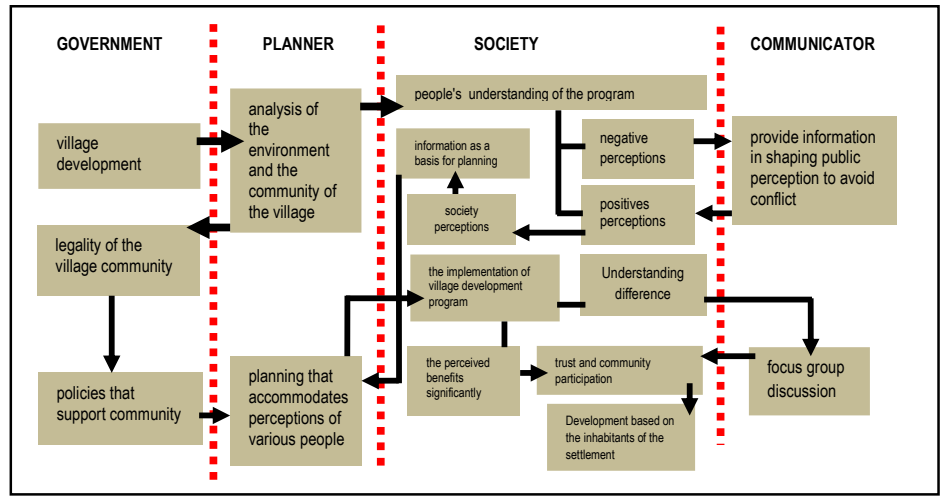

Figure 3: Communication Strategies in Generating The Community-Based Development (Source: Author Documentation)

\subsection{Conclusion}

The maritime settlement development program in Belawan Medan should accommodate opinions from all sides. Sometimes conflicts in the process of implementing a program become natural. In that case, the communicator can be a helpful way to solve the problem by building public perception. The community of fishing village in Belawan Medan can accept the role of communicator. The public wants the way of delivery to referring to the local wisdom of the physical state of the environment and the psychology of the inhabitants.

\section{Acknowledgement}

The researcher would like to thank PT. Directorate of Research and Community Service (DRPM) Indonesia in the Applied Superior Research Program of Higher Education (PTUPT) 2017 which has funded this research. Researchers continue to hope that the villagers of fishermen continue to open themselves to the process of village progress that context with local wisdom. 


\section{References}

Ahmad, P., Yusof, F. \& Abdullah, F. (2013).Local Economic Growth and Community Sustainability. Journal of Procedia - Social and Behavioral Sciences, 101, 437 - 444.

Akortor, E. S. A. (2012). Deliberative Democracy, An Analysis of Citizens Perspective in Buyukkonuk - North Cyprus. Journal of Procedia - Social and Behavioral Sciences,35, 301-312. doi:10.1016/j.sbspro.2012.02.092

Astuti, W., Astuti, D. W. \& Syarifudin, D. (2015). Contribution of Community-Based Development Toward Environment Improvement As an Effort of Poverty Alleviation. Journal of Procedia - Social and Behavioral Sciences, 179, 250-257. doi:10.1016/j.sbspro.2015.02.428

Bailer, S. (2010). What Factors Determine Bargaining Power And Success In EU Negotiations?. Journal of European Public Policy, 17 (5), 743-757

Bishop, K. \& Said, I. (2012). The Experience of Completing Qualitative Participatory Research in a Paediatric Setting: A Cross Cultural Comparison. Journal of Procedia - Social and Behavioral Sciences, 38, 73-80. doi: 10.1016/j.sbspro.2012.03.326

Daim, M. S., Bakri, A.F., Kamarudin, H. \& Zakaria, S. A. (2012). Being Neighbor to A National Park: Are We Ready for Community Participation?. Journal of Procedia Social and Behavioral Sciences, 36, pp. 214;219. doi:10.1016/j.sbspro.2012.03.024.

Dür, A. \& Mateo, G. (2010). Choosing A Bargaining Strategy In EU Negotiations: Power, Preferences, and Culture. Journal of European Public Policy, 17 (5), 680-693

GTZ Rioplus - Environmental Policy and Promotion of Strategies for Sustainable Development (2006). Strategic Communication for Sustainable Development: A Conceptual Overview,Eschborn, Germany:Schneller Druck, Reutlingen.

Ismail, W. A. W. \& Said, I. (2015). Integrating the Community in Urban Design and Planning of Public Spaces: A review in Malaysian Cities. Journal of Procedia Social and Behavioral Sciences, 168, pp. 363. doi: 10.1016/j.sbspro.2014.10.241

Jamaludin, M., Othman, N., \&Awang, A. R. (2012). Community Based Homestay Programme A Personal Experience. Journal of Procedia - Social and Behavioral Sciences, 42, 451 - 459. doi: 10.1016/j.sbspro.2012.04.210

Kang, M., Choo, P. \& Watters, C. E. (2015). Design for Experiencing: Participatory Design Approach With Multidisciplinary Perspectives. Journal of Procedia Social and Behavioral Sciences, 174, 830 - 833. doi: doi: 10.1016/j.sbspro.2015.01.67

Prabhakaran, S., Nair, V. \& Ramachandran, S. (2014). Community Participation in Rural Tourism: Towards A Conceptual Framework. Journal of Procedia Social and Behavioral Sciences, 144, 290-295. doi: 10.1016/j.sbspro.2014.07.298

Sesotyaningtyas, M. and Manaf, A. (2015). Analysis of Sustainable Tourism Village Development at Kutoharjo Village , Kendal Regency of Central Java. Journal of Procedia - Social and Behavioral Sciences, 184, 273 - 280. doi: 10.1016/j.sbspro.2015.05.091 